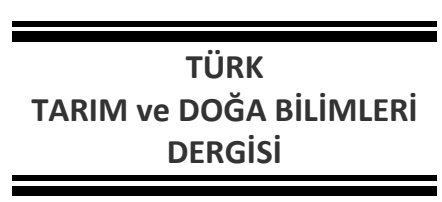

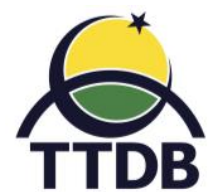

www.dergipark.gov.tr/turkjans

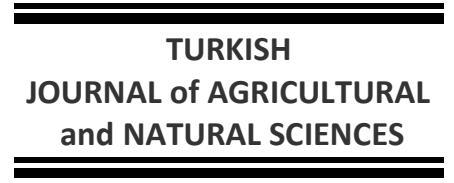

Araştırma Makalesi

\title{
Türkiye'de Bölgesel Düzeyde Tarımsal Üretim Değeri, Kadınların İşgücüne Katılımı ve Sermaye Stoku Arasındaki ílişkinin Panel Veri Analizi İle Karşılaştırması
}

\author{
Arzu KAN* \\ Kırşehir Ahi Evran Üniversitesi, Ziraat Fakültesi, Tarım Ekonomisi Bölümü, Kırşehir. \\ *Sorumlu yazar: arzu.kan@ahievran.edu.tr
}

Geliş Tarihi: 06.11.2018

Düzeltme Geliş Tarihi: 21.11.2018

Kabul Tarihi: 16.12 .2018

Özet

Kırsal alanda kadınlar gerek tarımsal üretime katkısı gerekse tarımsal üretimin sürdürülebilirliğinin sağlanmasındaki payı ile önemli bir rol oynamaktadır. Türkiye'de kırsalda kadınların emek açısından tarımsal üretim faktörleri içerisinde önemli katkıları bulunmaktadır. Girişimcilik açısından bakıldığında ise kadınlar son yıllardaki pozitif ayrımcılı̆̆ı sağlayan destekler ile iş hayatı içerisinde daha fazla yer almaya başlamışlardır. Türkiye'de tarım sektöründe Tarım ve Orman Bakanlı̆ı̆’nın kadını güçlendirmeye yönelik destekleri, Tarım ve Kırsal Kalkınmayı Destekleme Kurumu (TKDK-IPARD) projeleri ile kadın girişimciliğinin teşvik edilmesi, Küçük ve Orta Ölçekli İşletmeleri Geliştirme ve Destekleme İdaresi Başkanlığı (KOSGEB) ile kadınların iş kurmalarına yönelik destekler ve özel sektörün destekleri giderek artmaktadır. Bu çalışmada, özellikle kadının güçlendirilmesine yönelik teşviklerin kadının işgücüne katılım oranına ve buna bağlı olarak da tarımsal üretim değerine pozitif yönlü katkı yaptığı tezinden hareket edilmiştir. Ayrıca sermaye stoku olarak traktör varlığı değişkeni modele eklenerek üretim faktörleri içerisinde sermaye ve kadın işgücünün İstatistiki Bölge Birimleri Sınıflandırması 1 (IBBS1)'e göre tarımsal üretim değerleri arasındaki ilişkinin boyutunun ölçülmesi amaçlanmıştır. Toplam 12 iBBS1 içerisinde 14 yıllık (2004-2017) tarımsal üretim değeri, kadının tarımda işgücüne katılımı ve sermaye stoku olarak da traktör varlığı verileri Panel Veri Analizi (Autoregressive Distributed Lag-ARDL) ile incelenmiştir. Yapılan analiz ile kadının tarımda işgücüne katılımının ve traktör varlığının tarımsal üretim değerini pozitif yönlü etkilediği belirlenmiştir. Kadının tarımsal üretimin vazgeçilmez bir unsuru olduğu düşünüldüğünde tarım sektöründe kadının eğitiminin arttırılması, girişimcilik kapasitesinin yükseltilmesi, kaynaklara erişim konusundaki engellerin kaldırılması kadının kayıtlı işgücü piyasasında daha fazla yer almasını sağlayacağı ve tarımsal üretim değeri üzerinde pozitif etkisinin daha fazla olacağı söylenebilir.

Anahtar kelimeler: Kırsal kalkınma, tarımsal üretim, kadın işgücü, sermaye stoku, Türkiye.

\section{Comparison of Relationship Among the Agricultural Production Value, Participation of Women's Labour Force and Capital Stock by Panel Data Analysis in Regional Level of Turkey}

\begin{abstract}
Women play an important role in rural areas with their contribution to agricultural production and the providing sustainability of agricultural production. In rural of Turkey, the women have important contribution in terms of labor in agricultural production factors. In terms of entrepreneurship, women have started to take part in the business life with the supports which are enabling positive discrimination in recent years. The supports of Ministry of Agriculture and Forestry admitting of women empowerment in agriculture, promoting women's entrepreneurship with the Agriculture and Rural Development Support Institution (TKDK-IPARD) projects, the support for setting business of women with Small and Medium Enterprises Development Organization (KOSGEB) and private sector supports are increasing. In this study, it has been argued that the incentives towards women's empowerment contribute positively to the female labor force participation rate and accordingly to the value of agricultural production. In addition, the existence of tractor assets as a stock of capital was added to the model
\end{abstract}


to measure the size of the relationship between agricultural production values of the capital and female labor force according to Nomenclature of Territorial Units for Statistics 1 (IBBS1-NUTS1). 14-year (2004-2017) agricultural production value data in 12 NUTS1 Regions, the women labor force participation in agriculture and the presence of tractor as a stock of capital were examined with Panel Data Analysis (Autoregressive Distributed Lag-ARDL). With the analysis, it was determined that the women labor force participation in agriculture and the presence of the tractor have a positive effect on the agricultural production value. Considering that women are an indispensable element of agricultural production, it can be said that increasing the education and entrepreneurship capacity of women in the agricultural sector, and removing obstacles to access to resources will enable women to be more involved in the registered labor market and have a positive effect on the value of agricultural production.

Key words: Rural development, agricultural production, women labor, capital stock, Turkey.

\section{Giriş}

Maslow'un intiyaçlar Hiyerarşisi Teorisi'nin birinci basamağını oluşturan fizyolojik ihtiyaçların başında gıda gelmektedir. Gıda ihtiyacı karşılanmadığı sürece diğer ihtiyaçları oluşturan üst basamaklara geçiş söz konusu olmadığı düşünüldüğünde, tarımın sadece bir ülkede yaşayan insanların gıda ihtiyacını karşılayan bir sektör olarak görülmesi yanlış olacaktır (Erkuş ve ark., 2005). Tarım, insanlık yaşamının başladığı dönemden günümüzde geldiğimiz noktaya kadar gelişmenin her aşamasında katkı sağlayan ve her ülkenin her ne olursa olsun vazgeçemediği ve vazgeçmeyi de düşünmediği temel sektördür. Türkiye gibi gerek coğrafyası, gerekse iklimi tarımsal üretim için büyük bir potansiyelin olduğu ülkeler ise Dünya'nın temel üretim noktaları olarak önemini sürdürmeyi devam ettirecektir.

Türkiye ekonomisinde tarım; nüfus, istihdam, beslenme, tarımsal üretim, yurt içi tüketim, tarımın sanayiye olan katkısı, milli gelir ve ödemeler dengesi açısından önemini sürekli koruyan bir sektör konumundadır. Fakat gerek tarımın yapısal sorunları gerekse planlama boyutunda yaşanan aksaklıklar ve örgütlenme eksikliği bazı ürünlerde arz fazlası oluşturup üretici fiyatlarının düşmesine neden olurken bazı ürünlerde arz açı̆̆ı olması ve bu açığın ithalat yoluyla kapatılmasına neden olmaktadır. Ayrıca Türkiye'de farklı bölgelerin farklı üretim potansiyeline sahip olması flora ve fauna açısından zengin bir biyoçeşitliliğin ve genetik kaynak tabanının oluşmasına da imkan vermektedir. Türkiye'nin söz konusu bu potansiyeli tarımsal üretim değerine yansımış olup tarımsal katma değer üretimi bakımından 2017 yılı itibari ile 51.712 milyon \$ ile Dünya'da 8. sırada, Avrupa'da ise 1. sırada yer almaktadır (The World Bank, 2018) (Şekil 1).

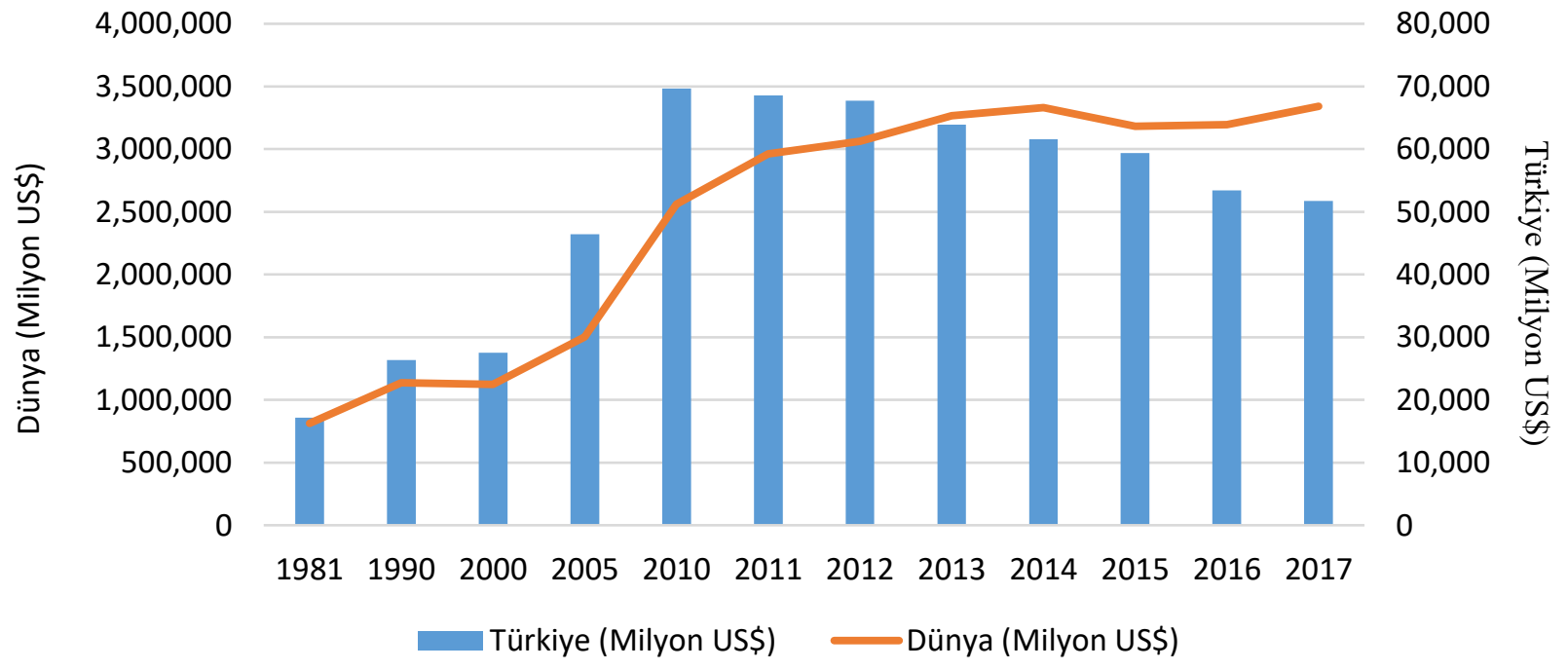

Şekil 1. Tarım, Orman ve Balıkçılık katma değerinin yıllara göre değişimi (Milyon US\$) (The World Bank, 2018).

1950’li yıllarda Marshall yardımları ile Türkiye'de tarımda makineleşmenin hız kazanması tarımdaki işgücü gereksiniminin düşmesine yol açarken, Türkiye'de sanayi hamlelerinin de gelmesi ile birlikte sanayi sektörünün işgücü ihtiyacının karşılanması aynı zamanda bu yıllarda kırsal göçün tetiklenmesine neden olmuştur (Şimşek ve Gürler, 1994; Güreşçi, 2010; Güreşçi, 2016). Son 
dönemlerdeki ekonomik göstergeler incelendiğinde tarımsal katma değerin Gayri Safi Hasıla (GSH)'daki ve istihdam içerisindeki payının giderek azaldığı gözlenmektedir. Tarım, orman ve balıkçılık katma değerinin GSH'daki payı 1997 yılında \%14.46, 2000 yılında \%10.08, 2016 yılında ise \%6.18 oranında gerçekleşmiştir (Şekil 2).

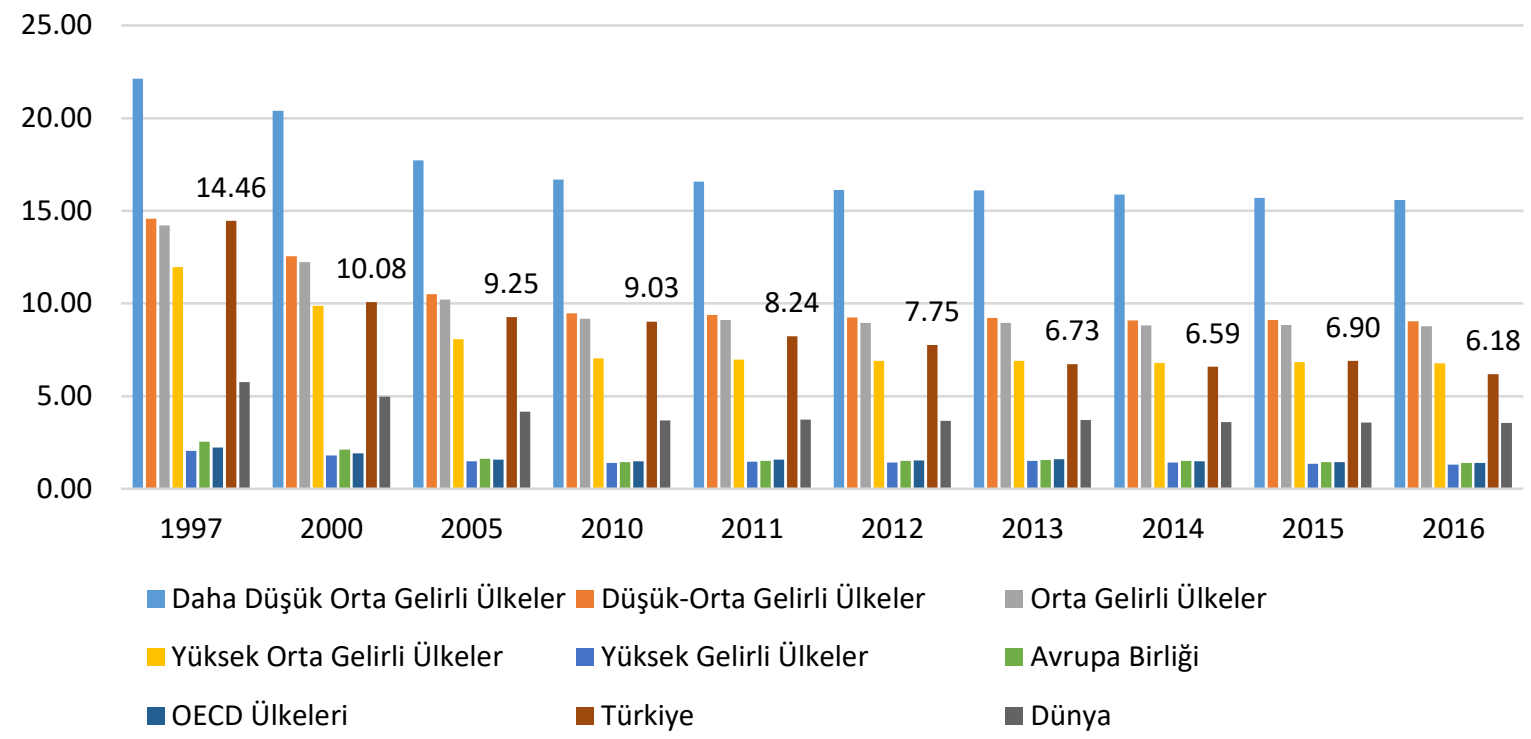

Şekil 2. Tarım, Orman ve Balıkçılık katma değerinin gayri safi hasıla içindeki payı (\%) (The World Bank, 2018).

Türkiye'de homojen bir üretimden ziyade farklı iklim ve toprak koşullarının bulunduğu bölgelerin olması nedeni ile heterojen bir yapının olduğunu söylemek mümkündür. İstatistiki Bölge Birimleri Sınıflandırması 1 (IBBS1)'e göre Türkiye'de 12 bölge bulunmaktadır ve her bölge sadece coğrafi olarak değil tarımsal üretim açısından da farklılık göstermektedir. Bu yapısı nedeni ile Türkiye tarımsal üretim açısından geniş varyasyonların olduğu üretim bölgelerine sahip olmuştur.

Şekil 3 incelendiğinde tarımsal üretim değeri açısından TRA, TRB ve TR1 bölgelerinin hayvancılık, TR6 ve TR9 bölgelerinin bitkisel ağırlıklı geri kalan bölgelerin ise karışık işletme tipinde (bitkisel ve hayvansal üretimin birlikte yapılması) üretim yaptıkları söylenebilir (TÜiK, 2018a; Karaman, 2018). TRA ve TRB bölgeleri Türkiye'nin doğu kesiminde iklimin daha sert olduğu ve coğrafi şekillerin özellikle bitkisel üretimden ziyade hayvansal üretim için daha uygun olduğu bölgelerdir. Söz konusu bölgeler Türkiye'de eşdeğer kişi başına yoksulluk sınırı bakımından en düşük bölgeleri oluştururken aynı zamanda satın alma gücü paritesi (SGP) bakımından da en yoksul alanları oluşturmaktadır (TÜiK, 2018b). Söz konusu bölgelerin toplam oluşturulan tarımsal üretim değeri Türkiye bölge ortalamasının altında olmasına rağmen en önemli tarımsal üretim değerini ise hayvansal üretim oluşturmaktadır.

Bitkisel üretimde tarımsal üretim değeri yaratan bölgelerin başında TR6 ve TR3 bölgeleri gelmektedir. Söz konusu bu bölgeler, Türkiye tarımsal üretimine değer katan en önemli iki bölgeyi oluşturmakta iken seracılık ve dış ticarette kayda değer yer tutan pamuk, incir, üzüm gibi bitkilerin önemli üretim merkezidir. Bunun yanı sıra tarımsal üretim değeri diğer bölgelere göre daha düşük olsa da Doğu Karadeniz Bölgesi çay ve fındık tarımının etkisi ile bitkisel üretim değeri hayvansal üretim değerinden daha fazla olan bölgelerdendir.

Üretim faktörleri içerisinde yer alan işgücü ve sermaye değişimi tarımsal üretim değerinin oluşmasında önemli faktörlerden olup, gösterge niteliğindedir. İşletmelerin entansite derecesi hakkında bilgi veren bu iki üretim faktörü bölgesel düzeyde işletme tiplerinin oluşmasını sağlamakta iken katma değeri yüksek olan ürün üretimi ile uğraşan bölgelerde işgücü ve sermaye kullanımı da daha yüksek oranda ortaya çıkmaktadır. Şekil 4'de yıllara ve IBBS1 bölgelerine göre bazı tarımsal göstergeler sunulmuştur. Reel tarımsal üretim değeri, traktör varlığı, erkek ve kadın işgücünün sunulduğu Şekil 4'de TR3 ve TR6 bölgelerinin diğer bölgelere göre entansif tarım sistemlerinin yoğunlukta olduğu görülebilir.

Tarımsal üretim içerisinde en önemli üretim faktörlerinden biri olan işgücü kullanımı, verimlilik ve kalkınma üzerine Türkiye'de çeşitli çalışmalar yapılmıştır. Kadın işgücü ve büyüme, kalkınma ve verimlilik konusunda yapılan çalışmalar kadın istihdamının (Gülçubuk, 1999; Berber ve Eser, 2008; Aydın, 2011; Günsoy ve Özsoy 2012; Serel ve Özdemir, 2017; Demir, 2018) kalkınmanın önemli bir göstergesi olduğunu göstermektedir. 


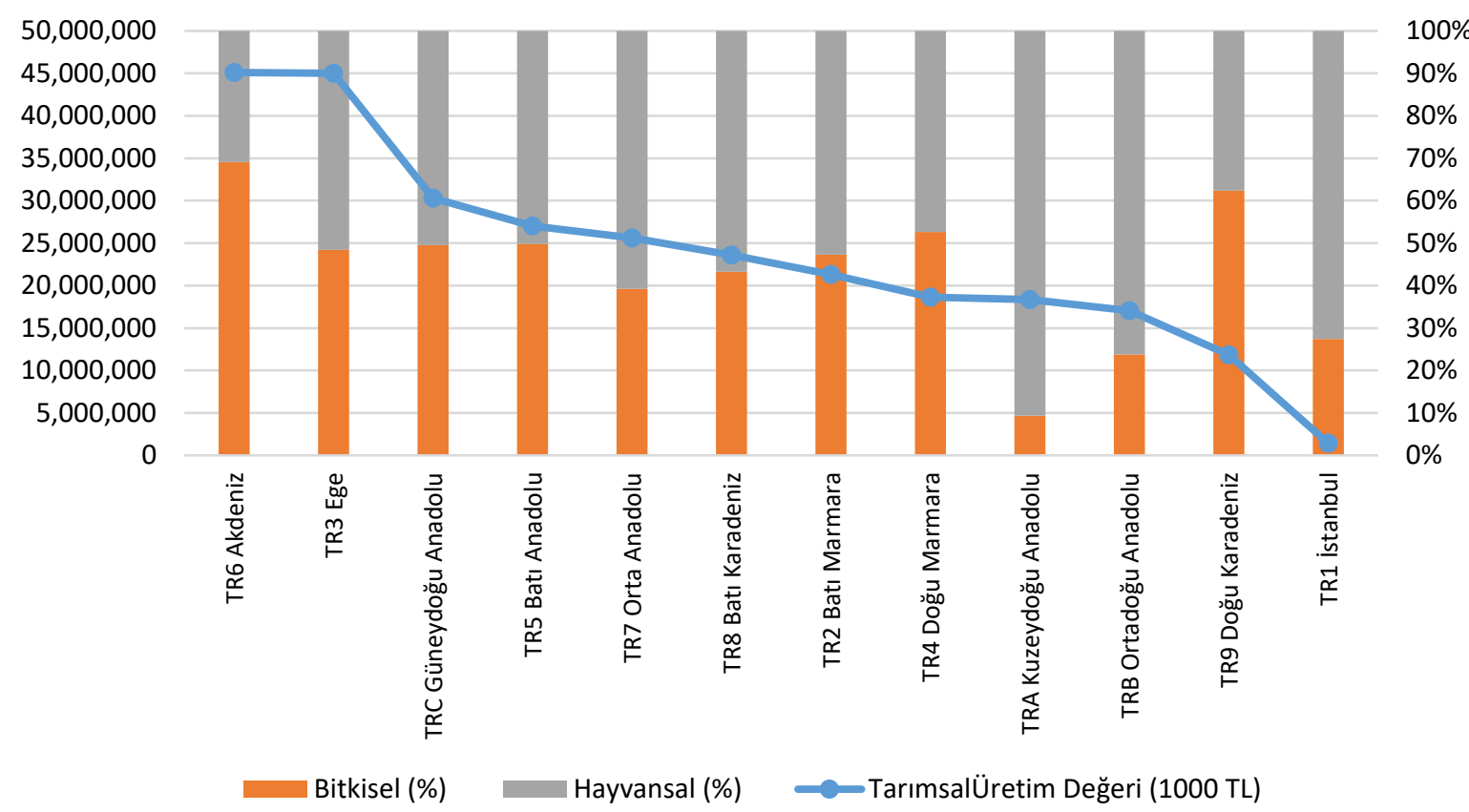

Şekil 3. İBBS1 Düzeyine göre tarımsal üretim değeri (1000 TL), bitkisel ve hayvancılık üretim değerlerinin payları (\%) (TÜIK, 2018a).
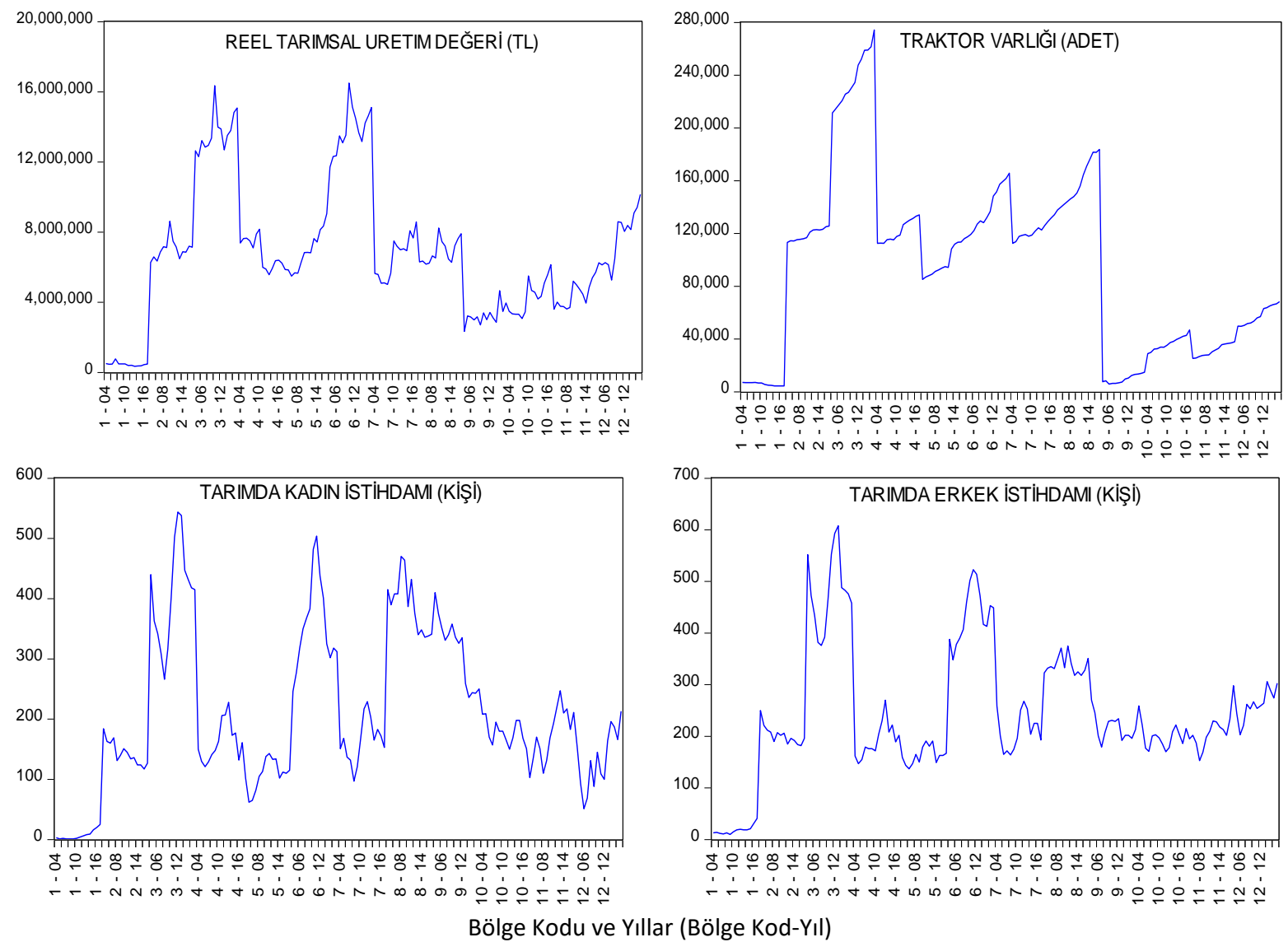

Şekil 4. 2004-2017 Yılları arasında IBBS1 bölgelerine göre tarımsal üretim değeri, traktör varlığı, kadın işgücü ve erkek işgücü göstergeleri (TÜiK, 2018a)

Gelişmiş ülkelerde kadın daha çok hizmet sektöründe istihdam edilirken gelişmekte olan ülkelerde ise kadının tarım sektöründe istihdam edildiği görülmektedir. Türkiye'nin kalkınması, kadının toplum içinde ve ekonominin tüm sektörleri içerisinde iş hayatında hak ettiği yere ulaşmasıyla 
doğru orantılıdır (Gülçubuk, 1999). Kadınlar toplum içinde dezavantajlı gruplar olarak belirtilen kesimi oluşturmakta ve kırsal alandaki kadınlar ise daha zor şartlarda çalışma ve yaşam şartları ile mücadele etmek zorunda kalmaktadır. Yoksulluk ve kaynaklara erişim konusunda en çok sorun yaşayan gruplardan biri olan kadınlar (Kan, 2014) tarımın görünmeyen kahramanları olarak nitelendirilmekte, Türkiye'de tarım sektöründe kayıt dışı olarak yoğun faaliyette bulunmakta ve daha çok ücretsiz aile işgücü olarak değerlendirilmektedir (Gülçubuk, 1999; Özer ve Biçerli, 2003; Berber ve Eser, 2008).

Çizelge 1'de Türkiye'de iBBS1 düzeyine göre farklı yıllarda toplam istihdamda ve tarımda kadın istihdamının payının oransal dağılımı verilmiştir
(TÜiK, 2018a). Bölgelere göre değişmekle birlikte kadın istihdamında genel ülke seviyesinde düşüş olduğu görülmektedir. Bunun yanı sıra artışların görüldüğü bölgeler olmakla birlikte (özellikle TRC, TR5, TR3 ve TR1 bölgelerinde bu artışlar göze çarpmakta) bu artışların yaşanmasında başta Tarım ve Orman Bakanlığı desteklerinin yanı sıra, işKUR, KOSGEB ve uluslararası fonların desteklerinin etkisi göz ardı edilemez. Kadın istihdamı ile birlikte tarımsal üretim değeri arasındaki ilişki de Şekil 4'de görülmekte olup kadın istihdamdaki eğilim ile tarımsal üretim değerindeki eğilimin TR3, TR5, TR6, TR7, TRB ve TRC bölgeleri ile aynı yönlü olduğu görülmektedir.

Çizelge 1. İBBS1 düzeyinde kadın istihdamının yıllara göre dağılımı

\begin{tabular}{|c|c|c|c|c|c|c|c|c|}
\hline \multirow[t]{2}{*}{ Bölge adı } & \multicolumn{4}{|c|}{$\begin{array}{c}\text { Kadınların toplam istihdam içindeki } \\
\text { payı (\%) }\end{array}$} & \multicolumn{4}{|c|}{$\begin{array}{c}\text { Kadınların toplam tarımsal istihdam } \\
\text { içindeki payı (\%) }\end{array}$} \\
\hline & 2017 & 2013 & 2010 & 2005 & 2017 & 2013 & 2010 & 2005 \\
\hline TR1 İstanbul & 0.44 & 0.17 & 0.05 & 0.03 & 37.88 & 29.63 & 12.50 & 6.67 \\
\hline TR2 Batı Marmara & 9.24 & 10.63 & 13.06 & 15.11 & 39.32 & 41.09 & 42.66 & 42.45 \\
\hline TR3 Ege & 10.36 & 14.18 & 12.27 & 12.47 & 47.59 & 46.95 & 46.31 & 43.42 \\
\hline TR4 Doğu Marmara & 5.67 & 8.37 & 7.43 & 6.78 & 44.35 & 45.78 & 48.66 & 46.93 \\
\hline TR5 Batı Anadolu & 4.13 & 5.53 & 6.29 & 3.49 & 40.93 & 41.23 & 43.40 & 30.10 \\
\hline TR6 Akdeniz & 9.03 & 12.48 & 16.05 & 11.50 & 41.00 & 45.83 & 48.98 & 44.32 \\
\hline TR7 Orta Anadolu & 11.87 & 15.96 & 15.48 & 16.68 & 44.22 & 44.52 & 46.15 & 45.53 \\
\hline TR8 Batı Karadeniz & 19.69 & 21.00 & 24.20 & 25.44 & 49.35 & 51.67 & 53.75 & 53.94 \\
\hline TR9 Doğu Karadeniz & 23.32 & 27.04 & 32.40 & 34.47 & 54.00 & 57.43 & 59.26 & 60.39 \\
\hline TRA Kuzeydoğu Anadolu & 21.15 & 24.21 & 27.36 & 30.87 & 44.81 & 48.70 & 47.75 & 48.38 \\
\hline TRB Ortadoğu Anadolu & 17.91 & 21.70 & 18.78 & 18.80 & 47.52 & 52.00 & 45.92 & 40.91 \\
\hline TRC Güneydoğu Anadolu & 10.25 & 9.40 & 9.37 & 7.46 & 41.28 & 38.41 & 35.19 & 27.68 \\
\hline Türkiye & 8.77 & 11.07 & 12.06 & 11.80 & 45.22 & 46.98 & 47.93 & 45.93 \\
\hline
\end{tabular}

Kadın tarımsal üretimin devamlılığında ana unsurlardan biridir. Ailenin geçim kaynağını her ne kadar erkek üstleniyor gibi görülse de kadının ailenin kırsalda kalması, tarımsal üretime devam etmesi ve üretimin çeşitlenmesindeki rolü çok önemlidir. Kadının tarımda kalmak istememesi nedeni ile evlilik kararlarını kente gidecek şekilde planlaması (Yılmaz, 2009), eğitim seviyelerinin artması ile kırsalda kadının kalması arasındaki ters ilişki (Yılmaz, 2009; Önder, 2013) kadının tarımda çalışma ve buna bağlı olarak da tarımda kadın istihdamının azalmasına sebep olmaktadır. Kadınların gelecekte çocuklarının tarımda kalmasını istememesi konusundaki tutumları da genç neslin tarımdan kopuşunu etkilemektedir. Tosun ve ark. (2018) genç çiftçilerle ilgili yaptıkları çalışmada TR71 Bölgesinde 2016 yılında Genç Çiftçi Projesi Desteği'nden yararlanan ve başvuru yapmış fakat yararlanamamış genç çiftçilerle görüşmüşlerdir (Örneklemeye giren kitlenin yaklaşık \%60'ını kadınlar oluşturmaktadır). Sonuç olarak çiftçilerin yaklaşık yarısı çocuklarının gelecekte tarımla uğraşmasını istememektedir. Eğitim imkanları, iş imkanları, sosyal imkanlar ve refah artışı gibi kavramlar gençlerin kırsalda ve tarımda kalmalarını etkileyen unsurlardır (Doğan ve ark., 2018). Bu nedenlerden dolayı kırsalda ailenin kalmasında ve tarımsal üretimin devamlılığında kadın önemli rol oynamaktadır.

Bu çalışmada, 2004-2017 yılları arasında tarımsal üretim değerinin oluşmasında kayıtlı kadın istihdamı ve sermaye stoku olarak ele alınan traktör varlığının İBBS1 düzeyindeki dağılımının etkisi Panel Veri Analizi metotları ile incelenmiştir. Kadınların tarımsal üretim değeri oluşturmada önemli katkıları olduğu düşüncesinden hareketle kadın istihdamının Türkiye'de tarımsal üretim değeri oluşturmadaki etkisi incelenmeye çalışılmıştır. Her ne kadar kadın istihdamı konusunda kayıt dışılık devam etse de bu çalışmanın sonuçları kadınların tarım sektöründe girişimciliğini desteklemeye yönelik teşviklerin de tarımsal üretim değeri oluşturmadaki etkisini görmek açısından önem taşımaktadır. Ayrıca sermaye stoku olarak traktör değişkeni modele konularak teknolojik ilerleme ile birlikte sermaye 
artışının tarımsal üretim değeri oluşturmadaki etkisi belirlenmeye çalışılmıştır.

\section{Materyal ve Yöntem}

Çalışma Türkiye için 12 iBBS 1 bölgesini dikkate alacak şekilde 2004-2017 yıllarını kapsamaktadır. Söz konusu dönemde IBBS 1 düzeyindeki bölgelere göre tarımsal üretim değeri, tarımda kadın istihdamı ve traktör mevcudiyeti değişkenleri kullanılmış ve bu değişkenlere ilişkin veri kaynakları ve kısaltmaları Çizelge 2'de verilmiştir.

Çizelge 2. Araştırmada kullanılan değişkenler, kısaltmalar ve veri kaynakları

\begin{tabular}{lccc}
\multicolumn{1}{c}{ Değişken } & Kısaltma & Birimi & Veri kaynağı \\
\hline Tarımsal Üretim Değeri & TÜD & Türk Lirası & TÜiK \\
Tarımda Kadın İstihdamı & TKi & Kişi & TÜík \\
Traktör Varlığı & TRV & Adet & TÜíK \\
\hline
\end{tabular}

Elde edilen veriler yardımıyla değişkenlere ait zaman serileri oluşturulmuştur. Araştırmada tam logaritmik form kullanılmıştır. Tarımsal üretim değerleri Tüik Üretici Fiyatları Endeksi (ÜFE 2003=100) dikkate alınarak reel değerlere çevrilmiştir. Tarımsal üretim değeri ile incelemeye alınan diğer değişkenler arasındaki fonksiyonel yaklaşım şu şekilde ifade edilebilir;

$$
\text { In TÜD = f(InTKi, InTRV) }
$$

Panel veri analizlerinde ele alınan değişkenler arasında uzun dönemli bir ilişkinin varlığı ile ilgili araştırma yapmadan önce, ele alınan değişkenlerde yatay kesit bağımlılığının olup olmadığının araştırılması gereklidir. Geleneksel birim kök testleri, genellikle yatay kesit bağımsızığı varsayımı altında çalışmaktadır. Yatay kesit bağımsızlığı varsayımını kullanabilmek için modele alınan panel verinin çok büyük bir yatay kesitten oluşması gerekmektedir. Yatay kesit ve zaman boyutlarının küçük olduğu panel modellerinde kesitler arasında ciddi korelasyonlar ortaya çıkabilir (Pesaran, 2004). Yatay kesit bağımlılığının dikkate alınmaması durumunda geleneksel panel tahmincileri ile yapılan tahminler yanıltıcı hatta tutarsız parametreler üretebilirler (Chudik ve Pesaran, 2013). Bu nedenle çalışmada yatay kesit bağımlılığının olup olmadığı, Breusch ve Pagan (1980) tarafından geliştirilen LM testi ve Pesaran (2004) tarafından geliştirilen CD testleri ile araştırılmıştır.

Eş bütünleşme analizinden önce ise analiz sonuçlarının güvenilir olması amacı ile eş bütünleşme denkleminde yer alan eğim katsayısının homojenliğini araştırmak için Swamy (1971) tarafından geliştirilen Swamy'nin S Testi kullanılmıştır.

Araştırmada birim kök sınaması yapılmıştır. Birim kök testi ile serilerin durağanlık araştırmaları yapılmaktadır. Birim kökün bulunduğu serilerden elde edilen sonuçlar yanlı olabilmektedir. Değişkenler arasındaki bağlanım sahte regresyon olarak boyutlanabilmektedir. Birim kök testi ile daha önce yapılan ve varsayımları ortaya koyulan birçok çalışma bulunmaktadır (Maddala ve Wu, 1999; Kao ve Chiang, 2000; Hadri, 2000; Choi, 2001; Levin ve ark., 2002; Im ve ark., 2003). Söz konusu çalışmalarda birim kök sınaması yapmanın önemine vurgu yapılmaktadır. Panel birim kök testlerinin gözlem sayısı artışından dolayı zaman serisi birim kök testlerinden istatistiksel olarak daha güçlü olduğu belirtilmektedir (Maddala ve Wu, 1999; Hadri, 2000; Levin ve ark., 2002; Im ve ark., 2003). Bu çalışmada panel veri modellerinde birim kök sınaması yapmak için kullanılan değişkenlerin durağanlığı yatay kesit bağımlılığını dikkate alan ikinci nesil CADF panel birim kök testi ile araştırılmıştır. İkinci nesil birim kök testleri, kesit birimleri arasındaki korelasyon durumunda ortaya çıkabilecek sonlu örnek özelliklerindeki sapmayı gidermek amacı ile geliştirilmiştir (Şak, 2018).

Ele alınan seriler arasında uzun dönem denge ilişkisinin varlığının belirlenmesi amacı ile Eş Bütünleşme analizi yapılmıştır. Üzerinde çalışılan panel veriyi oluşturan serilerden bir veya daha fazlası düzey halinde durağan yani I(0) ise Engle ve Granger (1987), Johansen (1988) ve Johansen ve Juselius (1990) önerdiği testler ile eş bütünleşme ilişkisi araştırılamaz. Bu nedenle çalışmada bu sorunu ortadan kaldıran Westerlund (2008) tarafından geliştirilen Durbin Hausman Eş Bütünleşme Testi kullanılmıştır. Bu testin en önemli özelliği, hem yatay kesit bağımlılığını dikkate alması hem de eğim katsayılarının heterojen olmasına izin vermesidir. Testin uygulanabilmesi için bağımlı değişken olarak ele alınan serinin birim kök içermesi gerekmektedir (Küçükaksoy ve Kalın, 2017).

Eş bütünleşme analizi sonucunda uzun ve kısa dönem etkilerin belirlenmesi için ARDL modeli uygulanmıştır. ARDL modelinin, küçük örneklemlerde güvenilir sonuçlar vermesi ayrıca hata düzeltme modeli ile uzun dönem bilgisi kaybedilmeden kısa ve uzun dönem dengesi bütünleşebilmesi bu modelin önemli avantajları arasındadır. Çalışmaya intibak ettirilmiş ARDL notasyonları aşağıdaki gibi ifade edilebilir; 


$$
\begin{aligned}
& \Delta \mathrm{TÜD}=\beta_{0}+\sum_{i=1}^{m} \beta_{1 i} \Delta \mathrm{TÜD}_{t-i}+\sum_{\substack{i=0 \\
m}}^{m} \beta_{2 i} \Delta \mathrm{TKI}_{t-i}+\sum_{i=0}^{m} \beta_{3 i} \Delta \mathrm{TRV}_{t-i}+\mathrm{a} 1 \mathrm{TÜD}_{t-1}+\mathrm{a} 2 \mathrm{TKI}_{t-1}+\mathrm{a} 3 \mathrm{TRV}_{t-1}+u_{t} \\
& \Delta \mathrm{TKI}=\mathrm{V}_{0}+\sum_{i=1}^{m} \beta_{1 i} \Delta \mathrm{TKI}_{t-i}+\sum_{i=0}^{m} \beta_{2 i} \Delta \mathrm{TÜD}_{t-i}+\sum_{i=0}^{m} \beta_{3 i} \Delta \mathrm{TRV}_{t-i}+\mathrm{a}_{m} \mathrm{TÜD}_{t-1} \text { a2TKI }_{t-1}+\mathrm{a} 3 \mathrm{TRV}_{t-1}+u_{t} \\
& \Delta \mathrm{TRV}=\mathrm{K}_{0}+\sum_{i=1}^{m} \beta_{1 i} \Delta \mathrm{TRV}_{t-i}+\sum_{i=0}^{m} \beta_{2 i} \Delta \mathrm{TÜD}_{t-i}+\sum_{i=0}^{m} \beta_{3 i} \Delta \mathrm{TKI}_{t-i}+\mathrm{a} 1 \mathrm{TÜD}_{t-1} \mathrm{a}_{2} \mathrm{TKI}_{t-1}+\mathrm{a} 3 \mathrm{TRV}_{t-1}+u_{t}
\end{aligned}
$$

Çalışmada değişkenler arasındaki nedensellik ilişkisini test etmek için Granger Nedensellik Analizi içerisinde yer alan metotlardan Stacked Test kullanılmıştır. Bu test, tüm panel birimlerinin (=bölgeler) gözlemleri büyük bir veri setinde toplandığı varsayımından hareket etmektedir. Bu yaklaşım, parametrelerin, farklı panel birimleri arasında değerlerinin aynı olduğu varsayımına dayanır, yani $i=1$ için $\beta i=\beta$ ve $\delta i=\delta$.. N. (Behringer ve ark., 2015). Granger Nedensellik Analizine yönelik notasyonu Eşitlik 5 ve 6' da görmek mümkündür.

$$
\begin{aligned}
& Y_{t}=\lambda_{0}+\sum_{i=1}^{n} \lambda_{i} Y_{t-i}+\sum_{i=1}^{n} \beta_{i} X_{t-i}+e_{t} \\
& X_{t}=\delta_{0}+\sum_{i=1}^{k} \delta_{i} X_{t-i}+\sum_{i=1}^{k} \sigma_{i} Y_{t-i}+u_{t}
\end{aligned}
$$

Eşitlik 5- $6^{\prime}$ da verilen $\lambda, \beta, \delta$ ve $\sigma$ değişkenlere ilişkin parametreleri, $n$ ve $k$ gecikme uzunluklarını, e ve $u$ ise hata terimlerini ifade etmektedir.

\section{Bulgular ve Tartışma}

Türkiye'nin kalkınması ile kadının hak ettiği yere ulaşması arasında doğrusal bir ilişki bulunmakta olup nüfusun büyük bir bölümünü oluşturan kadınların iş hayatına katılması ve zor koşullarda çalışma ve yaşam mücadelesi veren özellikle kırsal alandaki kadınların sorunlarının çözümü önem taşımaktadır. Kırsal alan denilince akla gelen en önemli sektör olan tarımda çalışan kadınların bu noktada ayrı bir şekilde ele alınması gerekmektedir. Toplumun en dezavantajlı kesimini oluşturan kadınlar bir o kadarda toplumun en önemli sorumluluğunu alan parçasını oluşturmaktadır. İnsanların temel ihtiyacını oluşturan tarım sektöründe gelişme az gelişmiş ve gelişmekte olan ülkelerde kadının mevcut statüsünün yükseltilmesi, görünür kılınması, hak ettiği değer ve ücretlere ulaşması ile mümkündür.

Türkiye tarımsal üretim değeri bakımından dünyada sayılı ülkeler arasındadır. Elde edilen bu üretim değerinin oluşmasında doğal koşullar kadar beşeri ve fiziki sermaye yapısı da önem arz etmektedir. Beşeri sermaye konusunda kadınlar tarım sektörünün görünmez kahramanları olup tarım sektörünün sürdürülebilirliğinde anahtar rolünde yer almaktadır. Maalesef Türkiye'de kadınlar tarım sektöründe daha çok ücretsiz tarım işçisi konumunda yer almakta olup istihdam istatistiklerinde yeterince görülmemektedir. Şekil 5 incelendiğinde yıllara göre tarımda istihdam edilen kadın sayısı dalgalanmalar göstermektedir. Kırsal kesimde kadın daha çok tarımda ücretsiz aile işgücü olarak yer alması nedeniyle yüksek oranda işgücüne katılımı söz konusu olmasına rağmen Türkiye'de tarımda istihdam hızla azalmakta ve buna bağlı olarak da kadın istihdamı giderek düşmektedir.

Kırsal alanda tarımda istihdam edilen kadınların çoğunluğu emek-yoğun işlerde çalışmakta ve söz konusu işler toplum içerisinde çoğunlukla düşük statülü olarak tanımlanmaktadır. Tarım kesimindeki kadınların üretime katılım düzeyleri, hanenin sahip olduğu arazi miktarına ve hayvan varlığına, işletmenin gelirine ve ürün deseninde yer alan bitki çeşitliliğine göre değişmektedir. Ancak, modern tarım sistemlerinin teknoloji ile birlikte tarımda yoğun kullanılması ile birlikte kadın tarımsal üretimden ayrılarak daha çok ev işlerine yönelmektedir. Geliri düşük ailelerde ise kadınlar mevsimlik işçilik başta olmak üzere bitkisel ve hayvansal üretimin her aşamasına katılmaktadır (Gülçubuk, 1999). 
120000

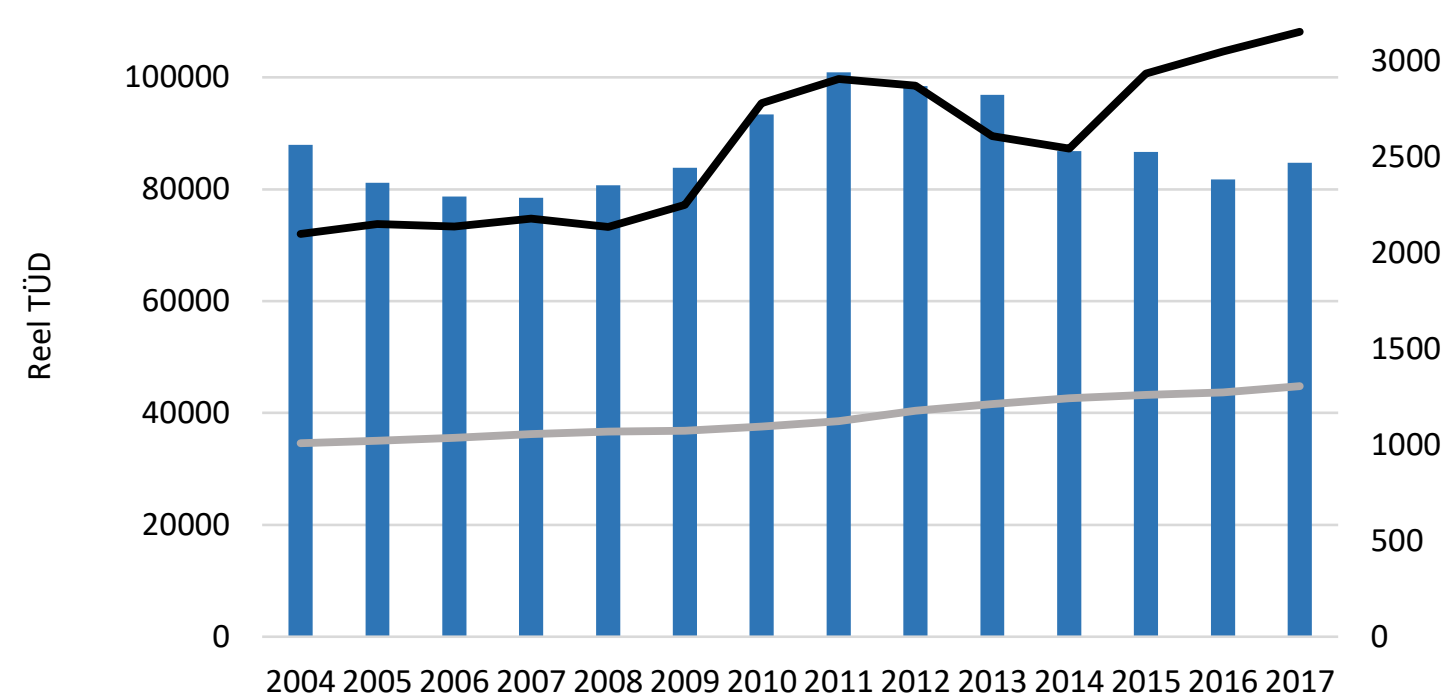

Şekil 5. Türkiye'de yıllara göre tarımda kadın istihdamı, reel tarımsal üretim değeri ve traktör varlığı değişimi (TÜiK, 2018a)

Fiziki sermaye açısından dikkate alınan traktör varlığı değişkeni incelendiğinde ise; Türkiye'de traktör varlığının artış trendi içinde olduğu belirlenmiş olup bu durum tarım işletmelerinde fiziki sermaye stokunda artışı işaret etmektedir. Bu artış aynı zamanda tarımsal üretim değerindeki artış ile kendisini göstermiştir (Şekil 5).

Çalışmada tarımsal üretimde en önemli iki faktör olan kadın işgücü ve sermaye stokunu dikkate alan traktör değişkeninin tarımsal üretim değerinin oluşmasındaki etkisi belirlenmeye çalışılmıştır. Çalışmanın hipotezinde kurulan panel setinde yer alan bölgelerin kadın işgücü ve sermaye stokları değişiminin, birbirini etkileyip etkilemediğinin araştırılması için yatay kesit bağımlılık testi, söz konusu bölgelerin birbirlerinden farklı olup olmadığının araştırılması için ise homojenlik testi yapılmış ve Çizelge 3'de sunulmuştur.

Çizelge 3. Yatay kesit bağımlılık ve homojenlik testi sonuçları

\begin{tabular}{lc}
\hline $\begin{array}{l}\text { Bağımlılık ve homojenlik } \\
\text { testleri }\end{array}$ & $\begin{array}{c}\text { Test } \\
\text { değerleri }\end{array}$ \\
\hline Breusch-Pagan LM & $183.407^{* *}$ \\
Pesaran scaled LM & $10.219^{* *}$ \\
Pesaran CD & $7.535^{* *}$ \\
Chi Square (Swamy S Testi) & $1498.280^{* *}$ \\
\hline **\%99 Güven sınırında istatistiki açıdan önemlidir.
\end{tabular}

Çizelge 3 incelendiğinde ele alınan yatay kesit bağımlılık testlerinde değişkenlerde yatay kesit bağımlılığı yoktur şeklindeki $\mathrm{H}_{0}$ hipotezi reddedilmektedir. Bölgelerde meydana gelen işgücü ve sermaye stoku ile ilgili değişimler ve bu değişimlere neden olan politikalar bölgeler arasında etkileşim içerisindedir. Beklenen bir durumu gösteren bu sonuç ile Türkiye'de kadın işgücünü ve sermaye stokunu arttırmaya yönelik politikaların bölgesel olmaktan çok ülkesel düzeyde olması bölgelerdeki değişimin birbirlerini etkilediği yargısına varılmaktadır. Homojenlik testi sonuçlarına bakıldığında ise her iki test istatistiği de, eğim katsayısının homojen olduğu yönündeki $\mathrm{H}_{0}$ hipotezini reddetmektedir. Tarımda kullanılan kadın işgücü ve sermaye stoku açısından bölgelerin hem tarıma elverişliliği hem de coğrafi yapılarının farklı tarım sistemlerinin uygulanmasına uygunluğu noktasında önemli farklılıklara sahip olmalarından dolayı bu sonuç da beklentilerle uyumludur.

Ekonometrik tahminlerde zaman serilerinin durağanlığı önemlidir. Granger ve Newbold (1974) durağan olmayan zaman serileriyle çalışılması halinde sahte regresyon problemiyle karşılaşılabileceğini belirtmiştir. Çalışmada kesit birimleri arasında yapılan bağımlılık testinde $\mathrm{H}_{0}$ hipotezinin red edilmesi sonucunda $\left(\mathrm{H}_{1}\right.$ Kabul: Kesitler yani bölgeler arasında bağımlılık vardır) kesit birimleri arasındaki bağımlılığı dikkate alan panel birim kök testlerinden biri olan Pesaran (2003) panel birim kök testi (CADF Test) yapılmıştır. Çizelge 4 durağanlık test sonuçlarını göstermektedir. 
Çizelge 4. Pesaran birim kök test sonuçları

\begin{tabular}{lcccccc}
\multicolumn{1}{c}{ Birim kök testleri } & \multicolumn{3}{c}{ Düzey sabitli } & \multicolumn{3}{c}{ Düzey sabitli trendli } \\
\hline TÜD & t-bar & Z(t-bar) & P Değeri & t-bar & Z(t-bar) & P Değeri \\
TKi & -2.443 & -2.267 & $0.012^{*}$ & -2.638 & -1.179 & 0.119 \\
TRV & -2.204 & -1.507 & 0.066 & -2.871 & -1.908 & $0.028^{*}$ \\
\hline & -2.492 & -2.421 & $0.008^{* *}$ & -2.637 & -1.177 & 0.120 \\
\hline TÜD & \multicolumn{3}{c}{$\Delta$ Sabitli } & \multicolumn{3}{c}{$\Delta$ Sabitli trendli } \\
TKi & -1.342 & 1.233 & 0.891 & -1.659 & 1.877 & 0.970 \\
TRV & -2.427 & -2.217 & $0.013^{*}$ & -3.236 & -3.046 & $0.001^{* *}$ \\
\hline
\end{tabular}

**\%99 Güven sınırında istatistiki açıdan önemlidir. *\%95 Güven sınırında istatistiki açıdan önemlidir.

2. nesil birim kök testi olan CADF testi yapılan seriler için analiz sonucu TÜD ve TRV serileri sabitli modelde düzeyde $\left(I_{0}\right)$ durağan iken, sabitli trendli modelde ise birim kök içermektedir. TKI serisinin ise sabitli modelde düzeyde birim kök içerdiği veya durağan olmadığı sabitli trendli modelde ise birim kök içermediği sonucuna ulaşılmıştır.

Çalışmada, kullanılan değişkenler arasında uzun dönemli bir ilişkinin olup olmadığı Durbin Hausman Eş Bütünleşme Testi ile araştırılmış ve analiz sonuçları Çizelge $5^{\prime}$ de sunulmuştur. Tarımsal üretim değeri, tarımdaki kadın istihdamı ve traktör varlığı arasındaki uzun dönemli ilişkinin araştırıldığı ve panel veri yapısının heterojenlik taşıdığını varsayan Durbin Hausman grup istatistikleri sonuçlarına göre $\mathrm{H}_{0}$ hipotezi (seriler arasında eş bütünleşme yoktur) reddedilmiştir. Sonuçlar değerlendirildiğinde, uzun dönemde 12 iBBS1 bölgesinde tarımsal üretim değeri, tarımdaki kadın istihdamı ve traktör varlığı arasında birlikte hareket söz konusu olup uzun dönemde etkiler mevcuttur yani eş bütünleşme vardır şeklinde yorumlanabilir.

Çizelge 5. Türkiye'de 2004-2017 yılları arası TÜRD düzeyini etkileyen faktörlere ilişkin Durbin Hausman eşbütünleşme testi sonuçları

\begin{tabular}{cccc}
\hline İstatistik & Değer & Z değeri & P olasılık değeri \\
\hline $\mathrm{G}_{\mathrm{t}}$ & -2.816 & -2.937 & $0.002^{* *}$ \\
$\mathrm{G}_{\mathrm{a}}$ & -3.070 & 3.344 & 1.000 \\
$\mathrm{Pt}_{\mathrm{t}}$ & -7.110 & -1.139 & 0.127 \\
$\mathrm{~Pa}_{\mathrm{a}}$ & -2.747 & 1.932 & 0.973 \\
\hline
\end{tabular}

**\%99 Güven sınırında istatistiki açıdan önemlidir.

$\mathrm{Bu}$ çalışmada ele alınan tarımsal üretim değeri, tarımda kadın istihdamı ve traktör varlığı faktörlerinin uzun dönemdeki etkileri kantitatif olarak ortaya koyulmuş olup, faktörlerin birbirleri ile interaksiyon içerisinde oldukları söylenebilir. Ancak bu ilişkinin yönü ve şiddeti hakkında Eş Bütünleşme Analizi ile yorum yapmak mümkün değildir. Bu nedenle tarımsal üretim değeri, tarımda kadın istihdamı ve traktör varlığı arasındaki ilişkinin uzun dönem etkisini ortaya koymak için ARDL analizi yapılmış ve sonuçlar Çizelge 6'da gösterilmiştir.
Çizelge 6. Türkiye' de 2004-2017 yılları arası tarımsal üretim değerini (TÜD) etkileyen faktörlere ait uzun dönem ARDL sonuçları

\begin{tabular}{ccc}
\hline Bağımlı değişken: & \multicolumn{2}{c}{ ARDL } \\
\cline { 2 - 3 } Ln TÜD & Katsayılar & t-istat. \\
\hline Ln TKi & 0.123 & $3193.934^{* *}$ \\
Ln TRV & 1.383 & $134.996^{* *}$ \\
\hline
\end{tabular}

**\%99 Güven sınırında istatistiki açıdan önemlidir.

Çizelge 6 incelendiğinde, ARDL sonuçlarına göre, Türkiye'de TÜD ile TKI ve TRV arasında istatistiki olarak \%99 güven sınırında aynı yönlü bir ilişki olduğu belirlenmiştir. Tarımsal üretim değeri ile tarımda kadın istihdamı interaksiyonu incelendiğinde aralarında pozitif yönlü bir ilişki bulunduğu, kadın istihdamındaki artışın tarımsal üretim değerine katkısının pozitif yönlü olduğu söylenebilir. Tarımda kadın emeği üzerine yapılan birçok çalışma bulunmakta ve bu çalışmaların en önemli ortak özelliği ise kadın istihdamının kayıt dışılığı (Lordoğlu, 1990; Olhan, 2011; Candan ve Özalp Günalp, 2013) üzerinedir. Son yıllarda kadın istihdamını geliştirmeye yönelik desteklerin verilmesi hem kadının kayıt altına alınması hem de tarımsal üretim değeri üzerine daha fazla katkı sağlamasına imkan vermektedir. Tarımda kadın istihdamının tarımsal üretim üzerine pozitif etkisi başta Tarım ve Orman Bakanlığı olmak üzere (IPARD dahil), Milli Eğitim Bakanlığı, KOSGEB, IŞKUR ve uluslararası kuruluşların kadınların güçlendirilmesine yönelik faaliyetlerinin de olumlu sonuçlarının bir göstergesidir. Burada dikkat edilmesi gereken en önemli unsur nicelik olarak meydana gelen artışın pozitif yönlü olmasında kayıt altındaki bu kitlenin nitelik yönü ile de tarımda çalışan kadınlardan daha iyi olmasından kaynaklanabileceği yönündedir. Kadınların tarımda kayıtlı işgücü piyasasına girmesinde etkili birçok neden bulunmaktadır. Özellikle 2000'li yıllarda ortaya çıkan tarımın feminizasyonu kavramı (Kulak, 2011) erkeğin tarımsal getirinin yeterli olmaması sonucu tarım dışı işlere yönelmesi, kadının ise bulunduğu yerde tarıma yoğunlaşması ve buna bağlı olarak üretimin her aşamasında karar süreçlerine 
daha fazla katılımını ifade etmektedir. Bunun sonucunda kadınların çoğu kez zorunlu olarak aldıkları bu statü nedeniyle tarımda organize olamayan daha fazla girişimcilik rolüne bürünmüş kadınlardan oluşan bir kesimin ortaya çıktığı görülmektedir. Yapılan çalışmalar eğitimli, tarımsal yayım hizmetleri başta olmak üzere kaynaklara ulaşabilen, mülkiyet sahibi kadınların kayıtlı işgücü piyasasına daha fazla giriş yapabileceklerini ortaya koymaktadır (Eser ve Gökmen, 2009; Kulak, 2011; Toksöz, 2011; Serel ve Özdemir, 2017).

Sermayenin üretimde daha yoğun kullanılması entansite derecesini dolayısıyla gayri safi üretim değerini pozitif yönlü etkileyen bir unsurdur (Semerci, 2016). Sermaye stoku bakımından traktör varlığı Türkiye'de tarımda sermaye kullanımı açısından bir faktör olarak değerlendirilebilir. Modelde ele alınan traktör varlığı değişkeninin model sonucunda tarımsal üretim değerini pozitif yönlü etkilediği belirlenmiştir (Çizelge 6). Katsayı açısından bakıldığında TRV'ye ait katsayının TKi katsayısından daha büyük oluşu tarımsal üretim değerinin oluşumunda teknolojiye dayalı üretimin daha yüksek getiri sağladığı sonucunu ortaya çıkarabilir.

Çizelge 7. Türkiye' de 2004-2017 yılları arası TÜD düzeyini etkileyen faktörlere ilişkin Granger Causality (Stacked Test Lag:1) Test sonuçları

\begin{tabular}{lc}
\hline Hipotez & F-stat \\
\hline TKi $\rightarrow$ TÜD & $5.065^{*}$ \\
TÜD $\rightarrow$ TKi & 0.363 \\
TRV $\rightarrow$ TÜD & 0.153 \\
TÜD $\rightarrow$ TRV & $25.054^{* *}$ \\
TRV $\rightarrow$ TKi & 0.028 \\
TKi $\rightarrow$ TRV & $22.998^{* *}$ \\
\hline
\end{tabular}

*\%95 Güven sınırında istatistiki açıdan önemlidir. **\%99 Güven sınırında istatistiki açıdan önemlidir.

Ele alınan değişkenlerin arasındaki ilişki ve bu ilişkinin yönü Granger Nedensellik Testi kullanılarak incelenmiştir. Çizelge 7 incelendiğinde TKi değişkeni ile TÜD değişkeni arasında tek yönlü bir ilişki olup tarımsal üretim değerindeki değişmede tarımda kadın istihdamı değişimi bir neden olarak görülmektedir. Kadının tarımsal üretimdeki önemi göz ardı edilemez. Tarımda kadınlar önemli görevler almasına rağmen kayıtlı olmamaları bir dezavantaj oluşturmakta kadınların kayıtlı olarak tarım istatistiklerine yansıması ile birlikte tarımsal üretime katkısı daha iyi görülebilmektedir. Tarımsal üretim değerindeki değişimin sermaye stokuna etki ettiği görülmektedir. Yapılan analizde de TÜD değeri TRV değerinin değişiminin nedeni olarak görülmekte ve tek yönlü bir ilişki bulunmaktadır. Buradan tarımsal üretim değerindeki artışın bölgelerde traktör satın almaya yönelik talebi arttırdığı sonucu çıkarılabilir.
Gerçekten de Türkiye'de traktör sahipliliği bir gereklilik olması yanında tarımın baskın olduğu kırsal toplumlarda bir statü özelliği taşımaktadır. Nedenselliğin bu şekilde belirlenmesi insanların bu yönlü bir davranış sergilemesinin de bir nedeni olabilir. TRV değişkeni ile TKi değişkeni arasında da tek yönlü bir nedensellik bulunmuş olup bu sonuç tarımda kadın istihdamının artışının traktör talebini de etkilediğini göstermektedir (Çizelge 7).

\section{Sonuç ve Öneriler}

Tarım sektörünün GSMH içindeki payı giderek azalırken toplam oluşturulan değer olarak tarım hem nitelik hem de niceliksel olarak artmaktadır. Katma değeri yüksek gıda ürünlerinin üretiminde tarımsal hammadde daha fazla yurtiçinde kullanılmakta iken sanayinin istediği birçok tarımsal hammadde için ise arz açığı ortaya çıkmaktadır. Bu süreç içerisinde teknoloji ve sermaye yoğun üretim aşamasında tarımın en önemli yürütücüsü ve gizli kahramanı olan kadınların, çalışma şartlarının iyileştirilmesi, tarımda kayıt dışı olan kadın emeğinin daha fazla görünür kılınması, kadınların niteliksel olarak geliştirilmesi, girişimcilik kapasitelerinin arttırılması ve daha fazla organize olmalarını sağlayacak örgütlenme modellerinin geliştirilmesi tarımsal üretimin hem miktar hem de değer olarak artmasına katkı sağlayacaktır.

İBBS1 düzeyinde analizlerin yapıldığı bu çalışma sonucunda tarımda kadınların toplam istihdam içindeki payının giderek düştüğü görülmektedir. Kadınların güçlendirilmesi amacı ile yapılan birçok programa rağmen kadın istihdamının görünür kılınmasındaki etki istenilen düzeyde olmayıp bu konuda daha fazla yol alınması gereklidir. Türkiye'de tarımın öncü bölgesi olan TR6 bölgesinde kadın istihdamında azalma göze çarparken tarımsal üretim açısından önemli olan TR3, TRC, TR5 ve TR7 Bölgelerinde tarımda kadın istihdamında artışlar bulunmaktadır. Söz konusu bu durum tarımdaki kadınları doğrudan veya dolaylı hedef alan desteklerin bölgesel yansımaları olup, tarımda kadın istihdamının tarımsal üretim değeri üzerindeki etkisine bu desteklerinde pozitif katkısı olarak değerlendirilmektedir.

Kadınların mülkiyet, eğitim, finansal hizmetler gibi üretken kaynaklara erişimlerinin artırılması, yeniden üretim faaliyetlerine ayırdıkları zamanın kısaltılması ve örgütlenmelerinin desteklenmesi yönünde gerçekleştirilecek çalışmalar tarım politikalarında serbestleşme eğilimlerinin giderek arttığı günümüzde kırsal alanda kadın istihdamının artırımasına katkı sağlayacaktır. Türkiye'de kadınların tarımsal gelişmede etkin rol oynayan kesimi oluşturdukları düşünüldüğünde bu kesimin güçlendirilmesi ve 
buna bağlı olarak tarım üzerindeki çarpan etkilerinin arttırılması günümüz tarım politikalarının en önemli bileşenlerinden birini oluşturmaktadır.

Türkiye'de tarımdan kaçışların bir diğer ifade ile kırsal alanlardan kentsel alanlara olan göçe karar verilmesi aşamasında ataerkil aile yapısından dolayı erkekler ön plandadır. Fakat tarımın sürdürülebilirliğinde kadın emeği göz ardı edilemez ve bu süreçlerde kadın her ne kadar göç kararında birincil karar verici olarak görülmese de erkeğin karar vermesine etkisinin büyük olduğu düşünülmektedir. Dolayısıyla bu konuda kadınların tarımda kalma istekliliklerini belirlemeye yönelik detaylı çalışmaların yapılması önerilmekle birlikte tarımsal üretimde değer artışında kadınlara yönelik politikalar arttırılarak devam ettirilmelidir.

\section{Kaynaklar}

Aydın, F. 2011. Kadın İstihdamının Rekabet Gücü ve Ekonomik Büyüme Üzerine Etkisi: Türkiye ile Rekabet Gücü En Yüksek Ülkelerin Karşılaştırılması. Yayınlanmamış Doktora Tezi, Erciyes Üniversitesi Sosyal Bilimler Enstitüsü, Kayseri.

Behringer, J., Stephan, S., Theobald, T. 2015. Macroeconomic factors Behind Financial Instability Evidence from Granger Causality Tests.

https://www.boeckler.de/pdf/v_2015_10_2 4_theobald.pdf.

Berber, M., Eser, B.Y. 2008. Türkiye'de kadın istihdamı: Ülke ve bölge düzeyinde sektörel analiz. İş, Güç, Endüstri ilişkileri ve insan Kaynakları Dergisi, 10(2): 1-16.

Breusch, T., Pagan, A. 1980. The Lagrange multiplier test and its applications to model specification in econometrics. The Review of Economic Studies, 47(1): 239-253.

Candan, E., Özalp Günalp, S. 2013. Tarımda kadın emeği. Tarım Ekonomisi Dergisi 2013; 19(1): 93-101.

Choi, I. 2001. Unit root tests for panel data. Journal of International Money and Finance, 20: 249272.

Chudik, A., Pesaran M.H. 2013. Common Correlated Effects Estimation of Heterogeneous Dynamic Panel Data Models with Weakly Exogenous Regressors. Federal Reserve Bank of Dallas Globalization and Monetary Policy Institute, Working Paper No. 146, Dallas.

Demir, N. 2018. Kadın İstihdamının Artırıması ve Kadınların İşgücüne Katılımlarının Belirleyicileri. Kalkınmada Anahtar Verimlilik, Kasım 2014, Sayı: 311. https://anahtar.sanayi.gov.tr/tr/news/kadin -istihdaminin-artirilmasi-vekadinlarinisgucune-katilimlarinin-belirleyicileri/1880
Doğan, H.G., Kan, A., Kan, M., Tosun, F., Uçum, i., Solmaz, C., Birol, D. 2018. Türkiye'de genç çiftçi proje desteğinden yararlanma düzeyini etkileyen faktörlerin değerlendirilmesi. Türk Tarım -Gıda Bilim ve Teknoloji Dergisi, 6(11): 1599-1606.

Engle, R.F., Granger, C.W.J. 1987. Cointegration and error correction: representation, estimation and testing. Econometrica, 55: 251-276.

Erkuş, A., Bülbül, M., Kıral, T., Açıl, F., Demirci, R. 2005. Tarım Ekonomisi. Ankara Üniversitesi Araştırma ve Geliştirme Vakfı Yayınları, Ankara.

Eser, K., Gökmen, Ç. 2009. Beşeri sermayenin ekonomik gelişme üzerindeki etkileri: Dünya deneyimi ve Türkiye üzerine gözlemler. Sosyal ve Beşeri Bilimler Dergisi, 41-56.

Granger, C., Newbold, P. 1974. Spurious regressions in econometrics. Journal of Econometrics, 2: 11-120.

Gülçubuk, B. 1999. Tarımsal Üretimde ve Kırsal Kalkınmadaki Kadının Yeri ve Önemi. T.C Tarım ve Köyişleri Bakanlığı, Tarım ve Köy Dergisi, Sayı: 125, Ankara, 36 s.

Günsoy, G., Özsoy, C. 2012. Türkiye'de kadın işgücü, eğitim ve büyüme ilişkisinin VAR analizi. Finans Politik \& Ekonomik Yorumlar, 49(568): 21-40.

Güreşçi, E. 2010. Türkiye'de kentten - köye göç olgusu. Doğuş Üniversitesi Dergisi, 11(1): 7786.

Güreşçi, E. 2016. Kırsal göçün sonuçları ve fırsatları. Türkiye XII: Ulusal Tarım Ekonomisi Kongresi, 25-27 Mayıs 2016, s.2137-2144, Isparta.

Hadri, K. 2000. Testing for stationarity in heterogeneous panel data, Econometrics Journal, 3: 148-161.

Im, K.S., Pesaran, M.H., Yongcheol, S. 2003. Testing for unit roots in heterogeneous panels, Journal of Econometrics, 115: 53-74.

Johansen, S. 1988. Statistical analysis of cointegration vectors. Journal of Economic Dynamics and Control, 12(2-3): 231-254.

Johansen, S., Juselius, K. 1990. Maximum Likelihood estimation and inference on cointegrationwith applications to the demand for Money. Oxford Bulletin of Economics and Statistics, 52(2): 169-210.

Kan, A. 2014. Kırsal Yoksulluğun Tarım ve Kadın Boyutu. 1. Basım, Editörler: A. Topçuoğlu, G. Aksan ve D. Alptekin, Yoksulluk ve Kadın, Ayrıntı Yayınları, İstanbul, Türkiye, 211-217 s.

Kao, C., Chiang, M.H. 2000. On the estimation and inference of a cointegrated regression in panel data, Nonstationary Panels, Panel Cointegration and Dynamic Panels, 15: 179222. 
Karaman, S. 2018. Türkiye bitkisel ve hayvansal üretim değerlerinin bölgesel düzeyde panel endeks ile karşılaştırmalı analizi. Yüzüncü Yıl Üniversitesi Tarım Bilimleri Dergisi (YYU J AGR SCI), 28(2): 168-174.

Kulak, E. 2011. Tarımsal Üretim Süreçlerindeki Değişimin Kırsal Alanda Kadın İstihdamına Etkileri: 1980 Sonrası Gelişmeler. Uzmanlık Tezi, T.C. Başbakanlık.

Küçükaksoy, ì., Akalın, G. 2017. Fisher Hipotezi'nin panel veri analizi ile test edilmesi: OECD ülkeleri uygulaması. Hacettepe Üniversitesi İktisadi ve İdari Bilimler Fakültesi Dergisi, 35(1):19-40.

Levin, A. Lin, C.F., James Chia, S.C. 2002. Unit root tests in panel data: asymptotic and finitesample properties. Journal of Econometrics, 108: 1-24.

Lordoğlu, K. 1990. Eve iş verme sistemi içinde kadın işgücü üzerine bir alan araştırması. Friedrich Ebert Vakfı Yayınları, İstanbul.

Maddala, G.S., Wu, S. 1999. A Comparative Study of Unit Root Tests with Panel Data and A New Simple Test. Oxford Bulletin of Economics and Statistics Special Issue, 0305-9049.

Olhan, E. 2011. Türkiye'de Kırsal İstihdamın Yapısı. Birleşmiş Milletler Ortak Programı "Herkes İçin İnsana Yakışır İş: Ulusal Gençlik İstihdam Programı ve Antalya Pilot Bölge Uygulaması". MDG Achivement Fund, FAO, iŞKUR.

https://media.iskur.gov.tr/13498/turkiyedekirsal-istihdamin-yapisi.pdf.

Önder, N. 2013. Türkiye'de kadın işgücünün görünümü. ÇSGB Çalışma Dünyası Dergisi, 1(1): 35-61.

Özer, M., Biçerli, K. 2003. Türkiye'de kadın işgücünün panel veri analizi. Anadolu Üniversitesi Sosyal Bilimler Dergisi, 3(1): 5585.

Pesaran, M.H. 2003. A Simple Panel Unit Root Test in the Presence of Cross Section Dependence. Cambridge Working Papers in Economics 0346, Faculty of Economics, University of Cambridge.

Pesaran, M.H. 2004. General Diagnostic Tests for Cross Section Dependence in Panels. IZA Discussion Paper, 1240.

Semerci, A. 2016. Tarımsal verimlilik düzeyleri ile Avrupa Birliği-Türkiye tarımı. Gaziosmanpaşa Üniversitesi Ziraat Fakültesi Dergisi (Journal of Agricultural Faculty of Gaziosmanpasa University) JAFAG, 33(3): 203-213.
Serel, H., Özdemir, B.S. 2017. Türkiye'de kadın istihdamı ve ekonomik büyüme ilişkisi. Yönetim ve Ekonomi Araştırmaları Dergisi, 15(3): 132-148.

Swamy, P.A.V.B. 1971. Statistical Inference in Random Coefficient Models. New York: Springer-Verlag.

Şak, N. 2018. Panel Birim Kök Testleri. "Alınmıştır: Uygulamalı Panel Veri Ekonometrisi. (ed.) Güriş, S. DER Yayınları, Yayın No:481, İstanbul, s. 261-309.

Şimşek, E., Gürler, Z. 1994. Kırdan kente göç olgusu ve kırsal sanayi. Türkiye 1. Tarım Ekonomisi Kongresi, 08-09 Eylül 1994, s.360-370, İzmir.

The World Bank, 2018. Agriculture, Forestry, and Fishing, Value Added (Current US\$). https://data.worldbank.org/indicator/NV.A GR.TOTL.CD?year_high_desc=true.

Toksöz, G. 2011. Kalkınmada Kadın Emeği. Varlık Yayınları, İstanbul.

Tosun, F., Solmaz, C., Uçum, İ., Kan, M., Kan, A., Doğan, H.G. 2018. Genç Çiftçi Desteklemelerine Kriter Olabilecek Parametrelerin ve Gençlerin Tarımda Kalma Eğilimlerinin Belirlenmesi-TR71 (Kırıkkale, Aksaray, Niğde, Nevşehir, Kırşehir) Bölgesi. Tarım ve Orman Bakanlığı, Tarımsal Araştırmalar ve Politikalar Genel Müdürlüğü, Tarımsal Ekonomi ve Politika Geliştirme Enstitüsü Müdürlüğü (Basılmamış Proje Raporu).

TÜiK, 2018a. IBBS1 Bölgelerine Göre Tarımsal Üretim Değeri, İşgücü ve Traktör İstatistikleri.

https://biruni.tuik.gov.tr/bolgeselistatistik/.

TÜiK, 2018b. IBBS1 Bölgelerine Göre Yoksulluk İstatistikleri.

http://tuik.gov.tr/PreTablo.do?alt_id=1013.

Westerlund, J. 2008. Panel cointegration tests of the fisher effect. Journal of Applied Econometrics, 23: 193-223.

Yılmaz, C. 2009. Türkiye'de kırdan kente göç sürecinde etkili olan faktörlerden biri; evlilik yoluyla göç. Doğu Coğrafya Dergisi, 14(21): 221-232. 